\title{
Framing the Community Data System Interface
}

DOI:

$10.1145 / 2783446.2783605$

Link to publication record in Manchester Research Explorer

\section{Citation for published version (APA):}

Garza Gutierrez, K., Goble, C., Brooke, J., \& Jay, C. (2015). Framing the Community Data System Interface. In Proceedings of the 2015 British HCl Conference (pp. 269-270). (British HCl '15). Association for Computing Machinery. https://doi.org/10.1145/2783446.2783605

\section{Published in:}

Proceedings of the 2015 British $\mathrm{HCl}$ Conference

\section{Citing this paper}

Please note that where the full-text provided on Manchester Research Explorer is the Author Accepted Manuscript or Proof version this may differ from the final Published version. If citing, it is advised that you check and use the publisher's definitive version.

\section{General rights}

Copyright and moral rights for the publications made accessible in the Research Explorer are retained by the authors and/or other copyright owners and it is a condition of accessing publications that users recognise and abide by the legal requirements associated with these rights.

\section{Takedown policy}

If you believe that this document breaches copyright please refer to the University of Manchester's Takedown Procedures [http://man.ac.uk/04Y6Bo] or contact uml.scholarlycommunications@manchester.ac.uk providing relevant details, so we can investigate your claim.

\section{OPEN ACCESS}




\section{Framing the Community Data System Interface}

\author{
Kristian Garza \\ University of Manchester \\ Oxford Road, UK \\ k.garza@manchester.ac.uk \\ John Brooke \\ University of Manchester \\ Oxford Road, UK \\ john.brooke@manchester.ac.uk
}

\author{
Carole Goble \\ University of Manchester \\ Oxford Road, UK \\ carole.goble@manchester.ac.uk \\ Caroline Jay \\ University of Manchester \\ Oxford Road, UK \\ caroline.jay@manchester.ac.uk
}

\begin{abstract}
Researchers in public funded science consortia agree that making their data accessible with the community is their obligation. Those mandated to use Community Data Systems (CDSs) prefer to share data with their collaborators and funders rather than make it open access. Their rationale to choose against open sharing includes the lack of incentives and lapses of memory. Features that address these two aspects are not included in current CDS implementations. We speculate that an interface framed as a device to secure data citations would positively influence researchers choices. We are performing a series of on-line experiments with subjects from the Life Sciences using the SEEK4Science platform as test-bed. One possible implication of our results is that Libertarian paternalism could be included in the Community Data Systems' design toolkit as a viable alternative to the current practices.
\end{abstract}

\section{CCS Concepts}

-Human-centered computing $\rightarrow$ HCI theory, concepts and models; Web-based interaction;

\section{Keywords}

Libertarian Paternalism, Open Research Data.

\section{INTRODUCTION}

Researchers in public funded science consortia agree that making their data accessible with the community is their obligation. Those mandated to use Community Data Systems (CDSs) prefer to share data with their collaborators and funders rather than make it open access. Their rationale to choose against open sharing includes the lack of incentives and lapses of memory. Features that address these two aspects are not included in current CDS implementations.

Permission to make digital or hard copies of part or all of this work for personal or classroom use is granted without fee provided that copies are not made or distributed for profit or commercial advantage and that copies bear this notice and the full citation on the first page. Copyrights for third-party components of this work must be honored. For all other uses, contact the owner/author(s).

British HCI 2015 July 13-17, 2015, Lincoln, United Kingdom

(C) 2015 Copyright held by the owner/author(s).

ACM ISBN 978-1-4503-3643-7/15/07 . .\$15.00

DOI: http://dx.doi.org/10.1145/2783446.2783605

\section{OUR APPROACH}

The use of Libertarian Paternalism in Web user interfaces has been shown to effectively modify user behaviour 2. Libertarian paternalism is a method used to influence selections in a way that will make choosers better off, as judged by themselves [5]. So far, however, no attempts to design Community Data Systems using libertarian paternalism to influence sharing have been implemented. By default, interfaces in these repositories are framed against the researcher main interest and motivations. Therefore, we propose to investigate the effects of a framed CDS interface on researchers sharing choices.

In a CDS the user interface challenges appear when the users are unable to decide to share their data openly. A framed CDS interface addresses that challenge by (1) reducing the complexity of the user decisions and (2) providing a "frame" aligned with the user motivations.

We speculate that researchers data sharing choices can be positively influenced by (1) an interface framed as a device to secure citations and (2) an interface designed with a structural selection mechanism for research data embargo periods.

\section{METHODOLOGY}

We performed a $2 \times 2$ cross-over study with subjects from the branches of Life Sciences. The treatments were designed using three techniques from libertarian paternalism: Emphasis framing (specific aspects of a solution are emphasised to encourage certain behaviour, and discourage certain others. 1]), Frame effects cues (offering "different, but logically equivalent phrases," which cause individuals to alter their preferences [1]) and Structural complex choice (lessen the choice complexity by architecting choices [5]).

\begin{tabular}{|l|l|l|}
\hline & Treatment & Control \\
\hline Frame Emphasis & Gain & Risk \\
\hline Frame effects & TRUE & FALSE \\
\hline Structural complex Choice & TRUE & FALSE \\
\hline
\end{tabular}

Table 1: Interventions implemented in the active treatment and control.

The subjects were asked to participate in the following scenario:

Imagine you are a Scientist participating in an International European collaboration. Imagine 
you and your collaborators just published a paper on your research. Your institution or funding body has requested that you and your collaborators publish your research data online once you have published your paper. Assume that there is a $80 \%$ chance that competitors - research groups in your domain from around the globe- will look at your data as soon as is open access.

The interventions were designed to modify the subjects' preferences with regards to (1) who they share data with and (2) which embargo periods they select when they decided against sharing data openly.

The theoretical population of the study is for (1) early academics in (2) a branch of Life Sciences that are (3) producers of research data/models in electronic form and (4) have work under a data sharing policy or initiative.

Study assessments:

- Awareness of the Frame effects cues was measured at the end of the experiment.

- User satisfaction of the interface was measures after interacting with each treatment 3 .

- A survey of users demographics and data sharing preferences was applied at the end of the experiment.

\section{RESULTS}

\subsection{Intervention 1: Emphasis Frame}

Our initial results have shown that under the Emphasis Frame treatment subjects select more open data sharing preferences, see Figure 1.

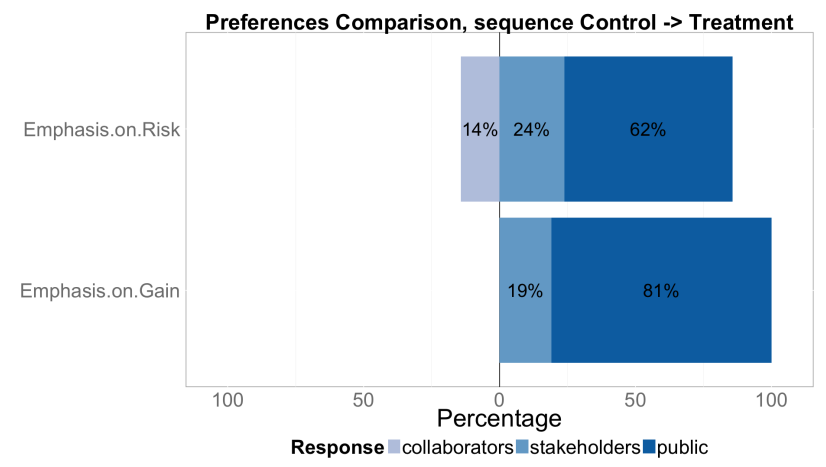

Figure 1: Preferences comparison between the control (top) and the framed interface (bottom). Darker categories are more open.

\subsection{Intervention 2: Structural Complex choice}

In terms of the Structural complex choice treatment subjects select shorter embargo periods than those under a free embargo period selection interface, see Figure 2

\section{DISCUSSION}

The results of our experiment suggest that CDS with an interface designed using an Emphasis Frame that emphasizes the potential of data citations can affect researchers' data sharing preferences from private to more open.

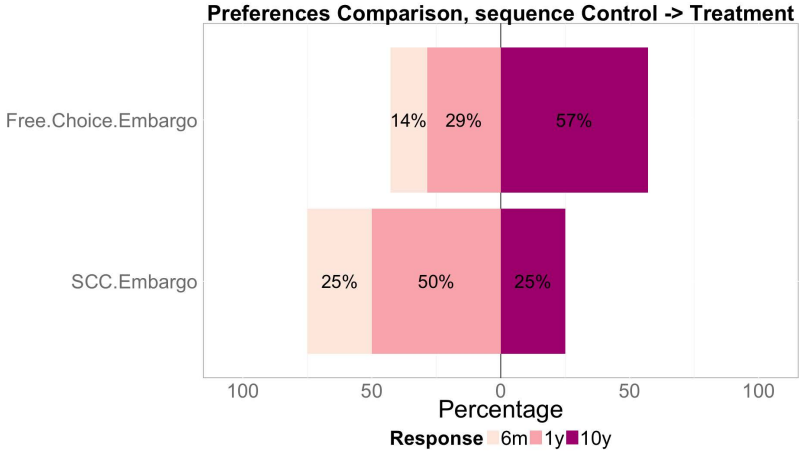

Figure 2: Embargo periods choices comparison. Showing the intervention with free choice embargo (top) and using Structural complex choice embargo (bottom). Lighter means shorter embargo periods.

Emphasis framing has been shown to affect behavior in other online contexts. For example, it has been argued, that success of large online peer-production systems could be influenced by the emphasis frame of the whole system 4]. Moreover, it has been shown that the inclusion of framing statements in web user interfaces influences user's judgment of user experience 2].

In the case of the Structural complex choice intervention for Embargo periods selection, the results although encouraging need to be judged with a larger sample. The current scenario of the experiment does not allow for the administration of this intervention to a larger number of subjects. Therefore, new scenarios should be attempted to statistically test this intervention.

So far our findings highlight the potential of framing interfaces, but a further evaluation needs to be completed. Additionally, the same experiment under different scenarios should be attempted. One possible implication of our results is that Libertarian paternalism could be included in the Community Data Systems' design toolkit as a viable alternative to the current practices.

\section{REFERENCES}

[1] D. Chong and J. N. Druckman. Framing Theory. Annual Review of Political Science, 10(1):103-126, 2007.

[2] J. Hartmann, A. D. Angeli, and A. Sutcliffe. Framing the user experience: information biases on website quality judgement, 2008.

[3] J. R. Lewis. IBM Computer Usability Satisfaction Questionnaires: Psychometric Evaluation and Instructions for Use. Int. J. Hum.-Comput. Interact., 7(1):57-78, Jan. 1995.

[4] B. Mako. Almost Wikipedia: What Eight Collaborative Encyclopedia Projects Reveal About Mechanisms of Collective Action. Berkman Center, 2010.

[5] R. H. Thaler and C. R. Sunstein. Nudge: Improving decisions about health, wealth, and happiness. Yale University Press, 2008. 